Commerce Division

Discussion Paper No. 106

\title{
REAL EFFECTS OF MONETARY \\ POLICY IN NEW ZEALAND
}

\author{
Md. Shahnawaz Karim \\ Minsoo Lee \\ and \\ Christopher Gan
}

October 2005 
Corresponding Author: Commerce Division, PO Box 84, Lincoln University, Canterbury, New Zealand, Tel: 64-3-960-9708, karimm2@lincoln.ac.nz, simi_v8@yahoo.com

Associate Professor, School of Business and Management, American University of Sharjah, PO Box 26666, Sharjah, United Arab Emirates, Tel: 971-6-515-2369, Fax 971-6-558-5066, mlee@ausharjah.edu

Associate Professor, Commerce Division, PO Box 84, Lincoln University, Canterbury, New Zealand, Tel: 64-3-325-2811, Fax 64-3-325-3847, ganc1@lincoln.ac.nz 
Commerce Division

Discussion Paper No. 106

\title{
REAL EFFECTS OF MONETARY \\ POLICY IN NEW ZEALAND
}

\author{
Md. Shahnawaz Karim \\ Minsoo Lee \\ and \\ Christopher Gan
}

October 2005

Commerce Division

PO Box 84

Lincoln University

CANTERBURY

Telephone No: (64) (3) 3252811 extn 8155

Fax No: (64) (3) 3253847

E-mail: ganc1@lincoln.ac.nz

ISSN 1174-5045

ISBN 1-877176-83-4 


\begin{abstract}
This paper analyzes the dynamic effects of unexpected domestic and foreign monetary policy shocks on 'industrial output' in New Zealand based on a 'new open economy macroeconomic' (NOEM) model. Empirical analyses are performed using unrestricted recursive open economy Vector Autoregressive (VAR) models involving policy and nonpolicy variables of New Zealand and four of its most important trading partners, i.e. Australia, Japan, United Kingdom and USA. The empirical findings are in accord with the qualitative predictions of monetary transmission channels relevant to a small open economy and no empirical anomalies are observed regarding the NZ output behaviour following a domestic restrictive monetary policy shock. Besides, the empirical findings also indicate that the full effects of a restrictive domestic monetary policy shock on industrial output in New Zealand are faster when Australian and US variables are included in the VAR model of monetary transmission compared to the cases when Japanese and UK variables are incorporated into the same model. On the other hand, domestic industrial output shows contraction due to a restrictive foreign monetary policy shock; reflecting the small open economy feature of New Zealand.
\end{abstract}

JEL classification: E42; E52; F41

Keywords: Output effects of monetary policy; New open economy macroeconomic model; Open economy benchmark VAR models; Monetary transmission channels; Restrictive monetary policy shocks 


\section{Contents}

List of Tables

List of Figures

1. INTRODUCTION 1

2. CHANNELS OF MONETARY TRANSMISSION MECHANISM AND

THE REAL ACTIVITY

3. THEORETICAL MODEL 3

3.1 First Order Conditions $\quad 6$

$\begin{array}{lll}3.1 .1 & \text { Initial Steady State Conditions } & 7\end{array}$

$\begin{array}{ll}3.1 .2 & \text { Model Dynamics }\end{array}$

4. METHODOLOGY 8

4.1 Structural Model 8

4.2 Reduced Form Model and Identification Scheme 9

5. DATA DESCRIPTION AND UNIT ROOT TESTS $\quad 11$

$\begin{array}{lll}5.1 & \text { Data Description and Sources } & 11\end{array}$

$\begin{array}{lll}5.2 & \text { Unit Root Tests } & 12\end{array}$

6. MODEL ESTIMATION, CO-INTEGRATION AND RESIDUAL

DIAGNOSTICS

7. DISCUSSION

8. CONCLUSIONS 


\section{List of Tables}

1. Unit Root Tests (Level) 20

2. Unit Root Tests (Difference) $\quad 21$

3. Co-integration Test Results (Trading Partners: New Zealand-Australia) 22

4. Lag Specification and Residual Test: Trading Partners: New Zealand-Australia 22

5. Lag Specification and Residual Test: Trading Partners: New Zealand-USA 23

6. Forecast Error Variance Decomposition of New Zealand Industrial OutputNew Zealand-Australia

7 Forecast Error Variance Decomposition of New Zealand Industrial OutputNew Zealand-Japan

8 Forecast Error Variance Decomposition of New Zealand Industrial OutputNew Zealand-USA

\section{List of Figures}

1. Real Effects of Domestic Monetary Policy Shocks in New Zealand 26

2. $\quad$ Real Effects of Foreign Monetary Policy Shocks in New Zealand 27 


\section{Introduction}

Since the inception of an explicit inflation targeting monetary policy in 1989 the Reserve Bank of New Zealand (RBNZ) has been quite successful in maintaining a low and stable inflation rate although some argue that the cost of achieving this target is considerably high in terms of forgone economic growth and employment. However, according to the best international practice, an inflation targeting central bank under flexible exchange rate system should concentrate on reducing the variability of output, price level and exchange rate instead of attempting to boost growth and employment.

Further, policy analyses generally concentrate less on the effects of monetary policy action on the real output than on its impacts on the CPI. The low exchange rate pass through due to pricing-to-market activities of international profit maximizing firms under imperfect competition could explain this bias in policy analyses. This paper analyzes the dynamic effects of unexpected domestic and foreign monetary policy shocks on 'industrial output' in New Zealand based on a 'new open economy macroeconomic' (NOEM) model. Empirical analyses are performed using unrestricted recursive open economy Vector Autoregressive (VAR) models involving policy and non-policy variables of New Zealand and four of its most important trading partners, i.e. Australia, Japan, United Kingdom and USA. Specifically, the dynamic analysis of domestic and foreign monetary policy innovations on New Zealand 'industrial output' is performed utilizing the Impulse Response Functions (IRF) and Forecast Error Variance Decomposition (FEVD) of the estimated benchmark open economy VAR models. Parallel to Favero (2001) and Cushman and Zha (1997) studies, the benchmark open economy VAR model is constructed based on the 'Wold' causal ordering that places the monetary policy variable on the assumption that RBNZ contemporaneously responds to fluctuations in domestic output while the latter responds only with a lag. The relevant variables are quarterly data, making it plausible to assume that RBNZ can observe output fluctuations at least within a quarter and implement appropriate monetary policy action. The impulse response functions are employed to simulate dynamic responses of non-policy variables that are exclusively due to monetary policy shocks. Similar to Sims (1986), one standard deviation positive innovation to New Zealand bank discount rate represents a domestic monetary contraction and the 'Choleski decomposition method' is used to identify the monetary policy shock.

Unexpected monetary policy actions transmit their effects on domestic macroeconomic variables through different channels known as the monetary transmission mechanism (MTM). 
Majority of the literature adopt ad-hoc empirical models to analyze the transmission mechanism of monetary policy without referring to the underlying macroeconomic models. Consequently, a considerable number of studies have failed to incorporate relevant policy and non-policy variables into the empirical models of monetary transmission, eventually resulting in empirical anomalies that are also known as 'puzzles' in the literature. The empirical analysis of this paper is based on a hybrid new open economy intertemporal general equilibrium model that allows pricing to market activities of imperfectly competitive profit maximizing firms integrating both 'producer currency pricing' (PCP) and 'local currency pricing' (LCP) strategies. The model is expected to generate more accurate policy implications than traditional Keynesian aggregative models. The NOEM models can be calibrated that involves matching unconditional moments (variances) generated by the model with the unconditional moments observed in the data. However, the calibration method cannot isolate the impacts on domestic real variables that are exclusively due to monetary policy shocks which represent a fraction of the overall economic fluctuations and as a result, this method is not quite accommodating for obtaining an overall empirical evaluation of the NOEM models (Lane Phillip, 2001). On the other hand, VAR models are considered the

natural empirical counterparts of open economy general equilibrium models and all the variables are treated with equal importance.

\section{Channels of Monetary Transmission Mechanism and the Real Activity}

The 'interest rate channel' is viewed as the most noticeable channel of the monetary transmission mechanism (MTM) that conspicuously explains how changes in nominal interest rate affect the real economic activity. MTM in open economies operates through 'exchange rate channel' (Svensson, 1997) in addition to other conventional channels. This direct channel of monetary transmission takes shorter time lag to transmit the impacts of monetary policy innovations to domestic output and price level. The RBNZ increases bank discount rate if it considers that current national output is significantly above its long run trend. An increase in New Zealand bank discount rate increases the market nominal interest rate that also translates into an increase in real interest rate given the short run price rigidity. As a result, cost of capital goes up and results in a decline in interest sensitive consumption and investment expenditure and consequently domestic output falls. On the other hand, an increase in NZ bank discount rate and nominal and real market interest rates also increase the demand for NZ dollar denominated bank deposits and causes an appreciation of nominal and real effective exchange rates. Consequently, the net export demand for domestic goods and 
services decline in New Zealand and eventually exerts a downward pressure on real activities and domestic industrial output. Finally, a restrictive domestic monetary policy stance increases the bank discount rate and causes a decline in the market interest rates. A decline in the prices of various domestic and financial assets follows in accordance with the inverse relationship between financial asset prices and the interest rates. This brings down domestic consumption expenditure through negative wealth effect and investment expenditure through 'Tobin's $q$ effect'. As a result, the real activity and industrial output in New Zealand may also decline.

\section{Theoretical Model}

This section describes the NOEM model parallel to Obstfeld \& Rogoff (1995) and Betts \& Devereux (2000) studies. The model assumes there are two countries; home and foreign, which are inhabited by optimizing households maximizing a utility function by intertemporally allocating the total income received from wages, profit, asset ownerships and government transfers among the available consumables. The home country is populated by a continuum of households (consumer-producers) continuously distributed within the range of ' 0 ' to ' $n$ ', while the foreign country households are distributed within the range of ' $n$ ' to ' 1 '. Both home and foreign households consume differentiated goods produced by profit maximizing firms under imperfect competition. The firms show asymmetric price setting behaviour. A certain proportion of home firms practice LCP-PTM (local currency pricing to market) strategy, whereas the rest of them follow PCP (producer's currency pricing) strategy. Further, it is assumed there are three sectors both at home and foreign, namely households, firms and government. The government in each country is assumed to execute monetary and fiscal policies. It raises funds through seigniorage (revenues earned from currency creation) and taxes imposed on the individual citizens that are redistributed to them in terms of transfers. The model is as follows:

Utility function: $U_{t}^{h}=\sum_{t=0}^{\infty} \beta^{t}\left[\log C_{t}^{h}+\chi \log \frac{M_{t}^{h}}{P_{t}}-\frac{\kappa}{2}\left(l_{t}^{h}\right)^{2}\right]$

$U_{t}^{h}$ stands for the current utility level of the home country representative household, whereas superscript ' $h$ ' stands for household and subscript ' $t$ ' expresses current period. $\beta^{t}$ expresses the discount ratio, $C_{t}^{h}$ is the real consumption index, $\frac{M_{t}^{h}}{P_{t}}$ denotes the real money balance, $\kappa$ 
shows the elasticity of substitution of labour for leisure and $l_{t}^{h}$ denotes the labour input employed.

The intertemporal budget constraint is given as follows:

$d_{t+1} B_{t+1}^{h}+M_{t}^{h}=B_{t}^{h}+M_{t-1}^{h}+w_{t} l_{t}^{h}+\pi_{t}^{h}-P_{t} C_{t}^{h}+P_{t} \tau_{t}^{h}$

where $B_{t}^{h}=$ total household nominal bond holdings at the end of period $t-1$ and maturing in period $t$.

$M_{t-1}^{h}=$ household money balance at the end of period $t-1$.

$w_{t} l_{t}^{h}=$ household wage income in period $t$.

$\pi_{t}^{h}=$ profits earned by domestic firms.

$P_{t} \tau_{t}^{h}=$ household transfer income at current prices obtained from the government.

$-P_{t} C_{t}^{h}=$ household income spent on current consumption.

$d_{t+1} B_{t+1}^{h}=$ total bond holdings of the representative home household at the end of period $t$ and maturing in period $t+1$.

and $M_{t}^{h}=$ household's nominal money balance in period $t$.

The real consumption index entering the utility function is denoted by equation (3), and equation (4) denotes the corresponding price index associated with the minimum possible nominal consumption expenditure for any given level of real consumption. $c_{t}^{h}(j)$ indicates the home country household's consumption of commodity $j$ and $\theta$ shows a 'proportionality coefficient'.

$$
\begin{aligned}
& C_{t}^{h}=\left[\int_{0}^{1} c_{t}^{h}(j)^{\frac{\theta}{\theta-1}} d j\right]^{\frac{\theta}{\theta-1}} \quad, \theta>1 \\
& P_{t}=\left[\int_{0}^{1} p_{t}(j)^{1-\theta} d j\right]^{\frac{1}{1-\theta}}
\end{aligned}
$$

Equation (4) also represents the general price index $\left(P_{t}\right)$ at home where $p_{t}(j)$ shows the current price of commodity $j$. Equation (4) can be modified to include the home currency and foreign currency prices of goods produced by home and foreign firms: 
$P_{t}=\left[\int_{0}^{n} p_{t}(h)^{1-\theta} d h+\int_{n}^{n+(1-n) s^{*}} p_{t}^{*}\left(h^{*}\right)^{1-\theta} d h^{*}+\int_{n+(1-n) s^{*}}^{1}\left(e_{t} q_{t}^{*}\left(h^{*}\right)\right)^{1-\theta} d h^{*}\right]^{\frac{1}{1-\theta}}$

Similarly, equation (6) denotes the foreign general price index expressed in terms of foreign and home currency prices of both foreign and home PCP and PTM firms.

$P_{t}^{*}=\left[\int_{0}^{n s} q_{t}(h)^{1-\theta} d h+\int_{n s}^{n}\left(\frac{p_{t}(h)}{e_{t}}\right)^{1-\theta} d h+\int_{n}^{1} q_{t}^{*}\left(h^{*}\right)^{1-\theta} d h^{*}\right]^{\frac{1}{1-\theta}}$

where $p_{t}(h)=$ home currency price of a commodity in period ' $\mathrm{t}$ ' produced by home firms practicing LCP-PTM (local currency pricing to market) and PCP (producer's currency pricing strategy).

$q_{t}(h)=$ foreign currency price of a commodity in period ' $\mathrm{t}$ ' produced by a home firm following LCP-PTM (local currency pricing to market) strategy only.

$p_{t}^{*}\left(h^{*}\right)=$ domestic currency price of a good in period ' $t$ ' produced both by foreign firms following LCP-PTM (local currency pricing to market) and PCP (producer's currency pricing strategy).

$\frac{p_{t}(h)}{e_{t}}=$ foreign currency export price of a good produced by a home firm following PCP (producer's currency pricing strategy).

$s=$ proportion of home firms practicing LCP-PTM (local currency pricing to market) strategy. $s^{*}=$ proportion of foreign firms practicing LCP-PTM (local currency pricing to market) strategy.

and $e_{t}=$ domestic currency price of the foreign currency.

The home country representative household has the following demand function embedded into the real consumption index:

$c_{t}^{h}(j)=\left[\frac{v(j)}{P_{t}}\right]^{-\theta} C_{t}^{h}$

The term $v(j)$ denotes the home currency price of $\operatorname{good} j$, which may be produced by either a home or foreign LCP-PTM or PCP firm. On the other hand, home currency profit function of a representative home firm following PCP and LCP- PTM strategies respectively can be expressed as follows. 
$\pi_{t}^{h}=p_{t}(h) y_{t}^{h}-w_{t} y_{t}^{h}$

$\pi_{t}^{h}=p_{t}(h) x_{t}^{h}+e_{t} q_{t}(h) z_{t}^{h}-w_{t}\left(x_{t}^{h}+z_{t}^{h}\right)$

The first term of equation (8) denotes total revenue while the second term indicates the labour cost of a home PCP firm. Equation (9) describes the profit function of a home LCP-PTM firm that earns total revenue from home and foreign markets where $x_{t}^{h}$ and $z_{t}^{h}$ denote the output levels exclusively produced for the home and foreign markets respectively. Given the consumer demand function in equation (7) and assuming price flexibility the profit maximizing price of both the home PCP as well as LCP-PTM firm can be expressed as follows:

$p_{t}(h)=\frac{\theta}{\theta-1} w_{t}$

Equation (10) shows that the representative price discriminating monopolistic home PCP or LCP-PTM firm sets its home currency product price (equal to its marginal revenue) as a mark-up of its marginal cost (equal to the wage rate), where the mark-up being equal to the ratio $\frac{\theta}{\theta-1}$. Price flexibility implies that the firms in both home and foreign countries can adjust their prices immediately in response to an exogenous shock. As a result, the Law of One Price prevails when prices are assumed to be flexible and goods prices will be the same across countries when the prices are translated in the same (home currency in this case) currency.

\subsection{First Order Conditions}

The first order conditions derived from the constrained lifetime utility maximization subject to the intertemporal budget constraint on behalf of the home country household yields the following equations signifying the optimal levels of household consumption, labour supply, money, and bond holdings:

Euler equation: $C_{t+1}^{h}=\beta\left(1+r_{t+1}\right) C_{t}^{h} \quad$ or $\quad \frac{\beta C_{t}^{h}}{C_{t+1}^{h}}=\frac{1}{1+r_{t+1}}$

Optimal Real Money Demand Function: $\frac{M_{t}^{h}}{P_{t}}=\chi C_{t}^{h}\left(\frac{1+i_{t+1}}{i_{t+1}}\right)$

Optimal Labour Supply Function: $\kappa l_{t}^{h}=\frac{w_{t}}{P_{t} C_{t}^{h}}$ 
In this scenario, the dynamic behaviour of home price level, output and exchange rate due to unexpected home and foreign monetary policy shocks can be derived using dynamic models involving the short and long run equilibrium conditions. The short run is denoted by the current period ' $t$ ' where both home and foreign LCP-PTM firms cannot change their product prices due to exchange rate variations caused by unexpected monetary policy shocks. On the other hand, the long run is denoted by the period $(t+1)$ where firms can incorporate the effects of monetary policy shocks in their production and pricing decisions. Finally, to derive the model dynamics, the model is solved for an initial steady state when nominal bond holdings are zero. A log linear approximation is then taken around the initial steady state solution of the model. To evaluate the effects of a monetary policy shock on the model variables, their rates of change are obtained from the initial pre-shock steady state.

\subsubsection{Initial Steady State Conditions}

An initial steady state is described as a condition when production and consumption are both held constant in the absence of a shock and the activity of a single representative agent describes the activities of all individual agents as these are assumed symmetric in the steady state.

Symmetric Steady State form of Euler equation:

$\bar{C}=\beta(1+\bar{r}) \bar{C}$ or $\bar{r}=\frac{1-\beta}{\beta} \equiv \delta$

Equation (14) shows that in the steady state the real interest rate is determined by the subjective discount rate. On the other hand, the intertemporal budget constraint of the home representative household combined with the goods and bonds market equilibrium yields the following equations that hold true in the steady state:

$$
n \bar{C}=\frac{n(1-\bar{d}) \bar{B}}{\bar{P}}+\frac{n(\bar{w} l+\pi+P \tau)}{\bar{P}} \text { or } n \bar{C}=\frac{n(1-\bar{d}) \bar{B}}{\bar{P}}+n \frac{(1-s) \overline{p y}+s(\bar{p} \bar{x}+\bar{e} \bar{q} \bar{z})}{\bar{P}}
$$

\subsubsection{Model Dynamics}

The dynamic behaviour of home and foreign price level, output and exchange rate due to unexpected monetary policy shocks at home and abroad can be presented as follows. Using the definitions of home and foreign price level from equations (5) and (6) the rates of their 
changes from their corresponding steady state levels can be expressed in terms of equations (16) and (17).

$\hat{P}_{t}=\frac{P_{t}-\overline{P_{0}}}{\bar{P}_{0}}=(1-n)\left(1-s^{*}\right) \hat{e}_{t}$

$\hat{P}_{t}^{*}=\frac{P_{t}^{*}-\overline{P_{0}}}{\overline{P_{0}}}=-n(1-s) \hat{e}_{t}$

where (1-n) and $n=$ foreign and home populations respectively.

and $\hat{e}_{t}=\frac{e_{t}-\bar{e}_{0}}{\bar{e}_{0}}=$ the rate of change of the exchange rate around its steady state level. Equation (16) implies that the higher the ratio of foreign PTM firms, i.e. higher the $s^{*}$, the lower will be $\hat{P}_{t}$ and vice of versa. The following equation indicates the short run depreciation of home currency exchange rate due to a monetary policy shock.

$\hat{e}_{t}=\frac{[2 \theta+\delta(\theta+1)]\left(\hat{M}_{t}-\hat{M}_{t}^{*}\right)}{\delta \theta(\theta+1)+2 \theta-\delta\left(\theta^{2}-1\right)\left[(1-n) s+n s^{*}\right]}$

Equation (19) reflects the home rate of production in terms of rates of change in home and foreign money supplies, where $\hat{Y}$ shows the rate of change in home output from its initial steady state level.

$\hat{Y}_{t}=\left[1+(1-n) \frac{2 \theta(\theta-1)\left[1-(1-n) s-n s^{*}\right]-[2 \theta+\delta(\theta+1)] s}{\delta \theta(\theta+1)+2 \theta-\delta\left(\theta^{2}-1\right)\left[(1-n) s+n s^{*}\right]}\right] \hat{M}_{t}$
$+(1-n) \frac{-2 \theta(\theta-1)\left[1-(1-n) s-n s^{*}\right]+[2 \theta+\delta(\theta+1)] s}{\delta \theta(\theta+1)+2 \theta-\delta\left(\theta^{2}-1\right)\left[(1-n) s+n s^{*}\right]} \hat{M}_{t}^{*}$

It can be shown that the coefficient of $\hat{M}_{t}$ (rate of change of home money supply from its initial steady state) is positive and the coefficient of $\hat{M}_{i}$ is either positive or negative depending on the values adopted by $s$ (domestic PTM firm ratio) and $s^{*}$ (foreign PTM firm ratio). Thus, it can be concluded that while relaxing the domestic monetary policy always increases domestic production since the coefficient of $\hat{M}_{t}$ is always positive in equation (19), the foreign monetary relaxation on the contrary may either increase (when the coefficient of $\hat{M}_{t}^{*}$ is positive) or decrease domestic production (when the coefficient of $\hat{M}_{i}^{*}$ is negative). 


\section{Methodology}

A benchmark unrestricted small open economy VAR model is estimated using the policy and non-policy variables of New Zealand and the most important trading partners. The model variables are ordered using 'Wold' causal chain and the structural parameters are recovered from the estimated reduced form parameters by 'orthogonalizing' the reduced form disturbances using 'Choleski’ decomposition method.

\subsection{Structural Model}

The structural VAR model involves a generic vector $\mathbf{x}_{\mathbf{t}}$, containing eight endogenous variables. A first order unrestricted VAR model describes the structural form of the empirical model in consideration with reference to the relationship (independent of lag length) between structural shocks and reduced form disturbances as follows:

$B x_{t}=B_{0}+\Gamma_{1} x_{t-1}+\varepsilon_{t}$

where

$$
B=\left(\begin{array}{ccccc}
1 & b_{12} & b_{13} & \cdots & b_{18} \\
b_{21} & 1 & b_{23} & \cdots & b_{28} \\
b_{31} & b_{32} & 1 & \cdots & b_{38} \\
\vdots & \vdots & \vdots & \ddots & \vdots \\
b_{81} & b_{82} & b_{83} & \cdots & 1
\end{array}\right), B_{0}=\left(\begin{array}{l}
b_{10} \\
b_{20} \\
b_{30} \\
\vdots \\
b_{80}
\end{array}\right), X_{t}=\left(\begin{array}{c}
Y_{t}^{\text {FOR }} \\
P C c_{t} \\
P_{t}^{\text {FR }} \\
R_{t}^{\text {FOR }} \\
Y_{t}^{N Z} \\
P_{t}^{N Z} \\
e x c_{t}^{N Z} \\
R_{t}^{N Z}
\end{array}\right), \Gamma_{1}=\left(\begin{array}{ccccc}
\gamma_{11} & \gamma_{12} & \gamma_{13} & \cdots & \gamma_{18} \\
\gamma_{21} & \gamma_{22} & \gamma_{23} & \cdots & \gamma_{28} \\
\gamma_{31} & \gamma_{32} & \gamma_{33} & \cdots & \gamma_{38} \\
\vdots & \vdots & \vdots & \ddots & \vdots \\
\gamma_{81} & \gamma_{82} & \gamma_{83} & \cdots & \gamma_{88}
\end{array}\right), \quad \varepsilon_{t}=\left(\begin{array}{c}
\varepsilon_{t}^{1} \\
\varepsilon_{t}^{2} \\
\varepsilon_{t}^{3} \\
\varepsilon_{t}^{\text {FOR }} \\
\varepsilon_{t}^{5} \\
\varepsilon_{t}^{6} \\
\varepsilon_{t}^{7} \\
\varepsilon_{t}^{R^{N Z}}
\end{array}\right)
$$

The structural shocks are exactly identified from the error terms of the estimated reduced form model using Choleski decomposition method.

where the Non-policy macroeconomic variables:

$Y_{t}{ }^{F O R}=$ foreign industrial production in current time period.

$\mathrm{Pcm}_{t}=$ 'world non-oil commodity price index'.

$P_{t}^{\text {FOR }}=$ foreign price level (CPI) in current period.

$Y_{t}^{N Z}=$ industrial production of New Zealand in current time period.

$P_{t}^{N z}=$ New Zealand price level (CPI) in current period.

$N E E R_{t}=$ nominal effective exchange rate index of New Zealand. 
and Policy variables:

$R_{t}^{\text {FOR }}=$ bank rate of the foreign country in consideration in current time period.

$R_{t}^{N z}=$ official cash-rate of New Zealand in current time period.

Orthogonalized residual of the Official Cash Rate equation, i.e. $\varepsilon_{t}^{R^{N Z}}$ denotes domestic monetary policy shock in New Zealand. On the other hand, the orthogonalized residual of the Bank Rate equation, i.e. $\varepsilon_{t}^{F O R}$ reflects a foreign monetary policy shock for New Zealand economy.

\subsection{Reduced Form Model and Identification Scheme}

The right hand side variables of equation (20) are correlated with the disturbance error terms and therefore it cannot be estimated using conventional estimation method such as the OLS. The structural model is transformed into the corresponding reduced form using $\mathrm{B}^{-1}$ provided that matrix B is non-singular. The model is estimated using OLS applied to each individual equation and the impulse response functions are obtained. Under the assumption that the structural shocks $\varepsilon_{t}$ 's are white-noise processes, their linear combinations $e_{t}$ 's are also assumed to be white-noise processes with zero means, constant variances and individually serially uncorrelated. The impulse response functions are derived by expressing the reduced form model (21) in terms of the VMA (Vector Moving Average), i.e. $x_{t}=\mu+\sum_{i=0}^{\infty} A_{1}^{i} e_{t-i}$.

$$
\left(\begin{array}{c}
Y_{t}^{\mathrm{FOR}} \\
P C m_{t} \\
P_{t}^{\mathrm{FOR}} \\
R_{t}^{\mathrm{FOR}} \\
Y_{t}^{N Z} \\
P_{t}^{N Z} \\
e^{N C_{t}^{N Z}} \\
R_{t}^{N Z}
\end{array}\right)=\left(\begin{array}{c}
a_{10} \\
a_{20} \\
a_{30} \\
a_{40} \\
a_{50} \\
a_{60} \\
a_{70} \\
a_{80}
\end{array}\right)+\left(\begin{array}{ccccc}
a_{11} & a_{12} & a_{13} & \cdots & a_{18} \\
a_{21} & a_{22} & b_{23} & \cdots & a_{28} \\
a_{31} & a_{32} & a_{33} & \cdots & a_{38} \\
\vdots & \vdots & \vdots & \ddots & \vdots \\
a_{81} & a_{82} & a_{83} & \cdots & a_{88}
\end{array}\right)\left(\begin{array}{c}
Y_{t-1}^{F O R} \\
P C m_{t-1} \\
P_{t-1}^{F O R} \\
R_{t-1}^{F O R} \\
Y_{t-1}^{N Z} \\
P_{t-1}^{N Z} \\
e x c_{t-1}^{N Z} \\
R_{t-1}^{N Z}
\end{array}\right)+\left(\begin{array}{c}
e_{t}^{1} \\
e_{t}^{2} \\
e_{t}^{3} \\
e_{t}^{R^{F O R}} \\
e_{t}^{5} \\
e_{t}^{6} \\
e_{t}^{7} \\
e_{t}^{R^{N Z}}
\end{array}\right)
$$

Invoking the relationship between reduced form error terms and the structural shocks, i.e. $e_{t}=B^{-1} \varepsilon_{t}$, the VMA is expressed as $x_{t}=\mu+\sum_{i=0}^{\infty} \phi_{i} \varepsilon_{t-i}$, where $\phi_{i}$ matrix denotes the impact multipliers. The Choleski decomposition method is used to recover the structural parameters from the reduced form model using the restrictions such that matrix B is lower triangular shown as follows. 


$$
\begin{aligned}
& b_{12}=b_{13}=b_{14}=\cdots \quad=b_{18}=0 \\
& b_{23}=b_{24}=\cdots \quad=b_{28}=0 \\
& b_{34}=b_{35}=\cdots \quad=b_{38}=0 \\
& b_{45}=b_{46}=\cdots \quad=b_{48}=0 \\
& b_{56}=\cdots \quad=b_{58}=0 \\
& b_{67}=\quad=b_{68}=0 \\
& b_{78}=0
\end{aligned}
$$

It is found that the benchmark unrestricted monetary VAR model incorporates 64 unknown free structural parameters including the elements in the variance-covariance matrix, whereas the estimated reduced form model contains 36 known free elements. The Choleski decomposition method requires $(64-36)=28$ zero restrictions on the structural model to identify its parameters from the reduced form model as shown in equation (22). Further, the Choleski decomposition method applied for the identification purpose also implies the following structure with reference to the relationship between structural shocks and reduced form errors, i.e. $e_{t}=B^{-1} \varepsilon_{t}$ or $e_{t}=C \varepsilon_{t}$, such that $C=B^{-1}$ where $\mathrm{C}$ is a unique matrix.

$$
\begin{gathered}
e_{1 t}=\varepsilon_{1 t} \\
e_{2 t}=c_{21} \varepsilon_{1 t}+\varepsilon_{2 t} \\
e_{3 t}=c_{31} \varepsilon_{1 t}+c_{32} \varepsilon_{2 t}+\varepsilon_{3 t} \\
e_{t}^{R^{F O R}}=c_{41} \varepsilon_{t}^{Y^{F O R}}+c_{42} \varepsilon_{t}^{P c m}+c_{43} \varepsilon_{t}^{P^{F O R}}+\varepsilon_{t}^{R^{F O R}} \\
e_{5 t}=c_{51} \varepsilon_{1 t}+c_{52} \varepsilon_{2 t}+c_{53} \varepsilon_{3 t}+c_{54} \varepsilon_{4 t}+\varepsilon_{5 t} \\
e_{6 t}=c_{61} \varepsilon_{1 t}+c_{62} \varepsilon_{2 t}+c_{63} \varepsilon_{3 t}+c_{64} \varepsilon_{4 t}+c_{65} \varepsilon_{5 t}+\varepsilon_{6 t} \\
e_{7 t}=c_{71} \varepsilon_{1 t}+c_{72} \varepsilon_{2 t}+c_{73} \varepsilon_{3 t}+c_{74} \varepsilon_{4 t}+c_{75} \varepsilon_{5 t}+c_{76} \varepsilon_{6 t}+\varepsilon_{7 t} \\
e_{t}^{R^{N Z}}=c_{81} \varepsilon_{t}^{Y^{F O R}}+c_{82} \varepsilon_{t}^{P c m}+c_{83} \varepsilon_{t}^{P^{F O R}}+c_{84} \varepsilon_{t}^{R^{F O R}}+c_{85} \varepsilon_{t}^{Y^{N Z}}+c_{86} \varepsilon_{t}^{P^{N Z}}+c_{87} \varepsilon_{t}^{e x c}+\varepsilon_{t}^{R^{N Z}}
\end{gathered}
$$

The last line of equation (23) stands for the RBNZ reaction function, implying that RBNZ monetary policy instrument $R_{N Z}$ contemporaneously responds to all domestic and foreign variables in consideration whereas the latter respond only with lags.

\section{Data Description and Unit Root Tests}

\subsection{Data Description and Sources}

The data series are collected from IFS CD ROM 2186990 except for the 'Australian short term interest rate' that is obtained from Lincoln University Database 'Econ Data'. Quarterly data series on relevant variables are used for the period 1985-2003. The data series start 
from 1985 as New Zealand changed to a floating exchange rate system in this year. Since full series monthly observations on all variables are unavailable, quarterly data series are used. The series on industrial production is a quarterly index with 1990 as the base year and these are seasonally adjusted by the IFS, while data series on other variables are seasonally adjusted using US Bureau of Census X11 Quarterly Seasonal Adjustment Program in EViews 5.1 software. The data series except for the interest rates (bank discount rates, short term interest rate, and short term Treasury bill rate) are log-linearized. While the quarterly series on NZ bank discount rate represents NZ monetary policy instrument, the data series on interest rates in the previously mentioned categories represent relevant foreign monetary policy instruments.

\subsection{Unit Root Tests}

The analyses begin with testing the stationarity status of the relevant variables using ADF and Phillips-Perron tests. Stationary time series variables are said to be integrated of order 0, i.e. $\mathrm{I}(0)$, while non-stationary variables are integrated of order 1 , i.e. I(1). Unit root tests on level data series (test results shown in table 1) are performed using more general autoregressive $\mathrm{AR}(p)$ processes. The Dickey-Fuller tests assume that errors in the test equations are independent white noise processes with constant variances. Test equations involve varying trend and intercept terms and optimal lag lengths are selected using H-Q criterion.

$$
\begin{aligned}
& \Delta y_{t}=\gamma y_{t-1}+\sum_{j=1}^{p-1} \beta_{i} \Delta y_{t-j}+e_{i} \\
& \Delta y_{t}=a_{0}+\gamma y_{t-1}+\sum_{j=1}^{p-1} \beta_{i} \Delta y_{t-j}+e_{i} \\
& \Delta y_{t}=a_{0}+\gamma y_{t-1}+a_{1} t+\sum_{j=1}^{p-1} \beta_{i} \Delta y_{t-j}+e_{i}
\end{aligned}
$$

According to the p-values of ADF and PP test statistics shown in table 1 the null hypothesis of a unit root is not rejected for any level data series in consideration except for LCPI $\mathrm{I}_{\mathrm{NZ}}$ (log of NZ consumer price index). The presence of statistically significant time trend coefficients in the relevant $\mathrm{ADF}$ and PP test equations imply that $\mathrm{LCPI}_{\mathrm{NZ}}$ is a stochastic process with a time trend. Table 2 shows the results of the ADF and the PP tests for the presence of a unit root in the first differenced data series. Reported p-values of ADF test statistics in table 2 
indicate that the null hypothesis of a unit root is rejected for all first differenced data series at $5 \%$ level of significance except for $\mathrm{LCPI}_{\mathrm{AU}}$ (log of Australian consumer price index). Further, the p-values of the PP test statistics indicate that the unit root null hypothesis is rejected for all first differenced data series at 5\% significance level. While both the ADF and PP tests have low power with regards to rejecting the 'non-stationary null' in the data series, however, prior research has not conspicuously indicated the relative superiority of one over another (Verbeek Marno, 2003). The PP test results show that all variables under study are I(1).

\section{Model Estimation, Co-integration and Residual Diagnostics}

Parallel to Sims, Stock \& Watson (1990) and Park \& Phillips (1988, 1989), the monetary VAR models in this paper are estimated in the levels of model variables using the OLS method applied to individual equations. Previous studies (Sims, Stock \& Watson, 1990; Park \& Phillips 1988; 1989) show that the OLS estimator possesses the same asymptotic properties as the maximum likelihood estimator (MLE) when the model variables are integrated of the same order and co-integrated. Since all the relevant variables are found I(1), Johansen-Juselius (1990) multivariate co-integration tests are performed to examine if these variables are co-integrated. Hence, the estimated reduced form model in equation (21) is expected to contain long run information as well as free from potential inconsistency (Favero, 2001). In order to test if the I(1) variables under study are co-integrated the following generalized VECM model is utilized that involves deterministic components such as trends and intercept terms.

$\Delta X_{t}=\Gamma_{1} \Delta X_{t-1}+\Gamma_{2} \Delta X_{t-2} \cdots \cdots+\Gamma_{k-1} \Delta X_{t-k+1}+\Pi X_{t-k}+\mu+\delta t+\varepsilon_{t}$

where $\delta=\alpha \delta_{1}+\alpha \perp \delta_{2}$ and $\mu=\alpha \mu_{1}+\alpha \perp \mu_{2}$ and $\alpha \perp$ is orthogonal matrix to $\alpha$ such that $\alpha^{\prime} \perp \alpha=0$. Besides, $\Pi=\alpha \beta^{\prime}$ such that $\beta$ denotes the vector of long run equilibrium parameters and $\alpha$ denotes the vector containing the speed of adjustment parameters, in case deviation occurs from the long run equilibrium relationships underlying the VECM model. There are three plausible VECM specifications according to the restrictions imposed on the deterministic components (trends and intercept terms). Model 1 and 5 are not considered since these are the most unlikely cases to occur in practice. Model 2 allows an intercept term in the co-integration space only, with no linear trends in the level data. Model 3 includes no linear trend either in level data or in the short run specification. Model 4 includes trend and intercept terms in the long run as well as an intercept term in the short run of the VECM. This 
model does not allow for a trend term in the short run part of the model. Consequently, in line with Johansen (1992c), the joint hypothesis of the rank order and deterministic components is tested for the estimated VAR models, in accordance with the 'Pantula principle'. Following the 'Pantula principle' three plausible VECM specifications are estimated and the results obtained are presented following an order from the most restricted specification (i.e. $r=0$, and Model 2) reported first to the least restricted alternative (i.e. $r=n-1$, and Model 4) reported last (see table 3). The testing procedure under this principle proceeds by moving from the most restrictive specification to the least restrictive one and comparing the test statistic (Maximum Eigenvalue or Trace) with its critical value. Testing stops only when the null hypothesis is not rejected for the first time and the corresponding value of ' $r$ ' indicates the number of co-integrating relationships among the model variables. The arrows in table 3 show that the null hypotheses regarding the corresponding co-integrating vector are rejected based on the $5 \%$ critical value of the test statistic. According to $\lambda_{\max }$ test, it may be concluded that there are 3 co-integrating relationships underlying the VECM (model 3) specification pertaining to the estimated New Zealand-Australia model. The $\lambda_{\max }$ test also detects 5 cointegrating relationships under the VECM (model 3 and 2) specifications for the New Zealand-Japan and New Zealand-UK models respectively. In case of New Zealand-USA model, the $\lambda_{\max }$ test finds 2 co-integrating relationships under VECM (model 3) specification. Next, the VAR models are estimated initially using 4 lags due to quarterly nature of the data and 'lag length selection criteria' is used for this purpose. The lag selection and residual diagnostic tests for two of the estimated reduced form VAR models are shown in tables 4 and 5. In the New Zealand-Australia model, 3 lags are chosen by the model selection criteria and the 'Wald' lag exclusion test' rejects the null hypothesis of a smaller lag. On the other hand, the New Zealand-USA model is estimated using only 2 lags (supported by HQ criterion) as relatively high residual autocorrelation is found for VAR(4) according to Breusch-Godfrey LM test. The New Zealand-Japan and New Zealand-UK models are estimated using 4 lags.

All models are found stationary and no significant residual 'Heteroskedastacity' is detected in the models. Although the 'multivariate normality tests' (Lütkepohl type) has not found significant 'Skewness' in either model but significant excess 'Kurtosis' is detected in all models. The 'Jarque-Bera' test rejects the normality assumption for all models except for New Zealand-USA model for which the null hypothesis of normality is marginally accepted. Finally, except for one or two lags, no significant residual autocorrelation is found in the estimated models according to Breusch-Godfrey LM test. 


\section{Discussion}

Figure 1 shows the output effects of domestic monetary contraction in New Zealand. The domestic monetary contraction is indicated by the 'one standard deviation positive innovation' to the New Zealand bank discount rate in the estimated benchmark VAR models of international monetary transmission. Two standard error bounds are shown by the dashed lines in the impulse response graphs. In all cases the output significantly falls after the first quarter following a domestic monetary contraction in New Zealand and continues to fall at least for several quarters before reaching the pre-shock level, implying the temporary output effect of monetary policy. Therefore, the dynamic behaviour of New Zealand 'industrial production' in response to the domestic monetary contraction is not quite sensitive across the major trading partners. However, from the standpoint of intensity and magnitude the output effect of monetary policy may differ depending on which trading partner is considered. The impulse response functions show that the maximum output effect of domestic monetary contraction in New Zealand is realized within 3 quarters with reference to the trading partnership with Australia and the USA. In case of trading partnership with Japan and UK the maximum output effects of domestic monetary contraction in New Zealand are visible within 4 quarters. New Zealand output declines to the minimum of 0.5 percent from the pre-shock level following a domestic monetary contraction for a trading partnership with Australia. In case of a trading partnership with the USA, the output in New Zealand declines to the minimum of 0.3 percent from the pre-shock level after the tight monetary policy is implemented at home. For a trading partnership with Japan and UK, the industrial output in New Zealand decline to the minimum of 0.4 and almost 0.2 percent respectively from the preshock levels following the domestic monetary contraction.

Figure 2 shows the output effect of foreign monetary contraction in New Zealand. The impulse response functions of New Zealand industrial production are estimated due to 'one standard deviation positive innovations' to the foreign monetary policy variables. The first graphs of figure 2 show that New Zealand bank discount rate increases due to positive innovations to foreign monetary policy instruments (bank discount rates in Japan and US, short term interest rate in Australia and Treasury bill rate in the UK). The positive impulse response in New Zealand bank discount rate may take place either because the RBNZ is likely to replicate the restrictive monetary policy stance of the larger trading partners being the central bank of a small open economy or it may respond to the monetary contraction of the 
major trading partners by increasing the bank discount rate in order to avoid the inflationary effect of domestic currency depreciation. The foreign monetary contraction necessitates currency depreciation in New Zealand, which is short-lived due to the overshooting behaviour of exchange rates; typical for the small open economies. This short lived New Zealand domestic currency depreciation is captured in the impulse response graphs on the second column of figure 2. Except for Australia, monetary contractions in the major trading partners have caused impact depreciation of domestic currency in New Zealand that lasts for a relatively short period. The output effect of foreign monetary contraction in New Zealand depends on the relative strength of domestic interest rate hike and short term exchange rate depreciation. Specifically, a foreign monetary contraction may dampen New Zealand aggregate demand and output by increasing the domestic interest rate and at the same time may also expand domestic demand and output by causing short term domestic exchange rate depreciation. For the small open economy of New Zealand, domestic interest rate rises in tandem with those of the major trading partners and the first effect dominates the second one. Therefore domestic output falls significantly following the foreign monetary contraction and then tends to return to its pre-shock level as shown in the impulse response graphs on the third column of figure 2 .

Table 6, 7 and 8 show the sources of fluctuations in New Zealand industrial production due to various shocks using the forecast error variance decomposition method. The forecast horizons at which the forecast errors are calculated are shown on the top row of these tables. The shocks in the 'world non-oil commodity price index' (PCM) and foreign monetary policy shocks explain a relatively large part of output fluctuations in New Zealand, especially in the long run. For a trade partnership with Japan, PCM explains 23 percent fluctuations in New Zealand industrial output at the peak at a 40- quarter horizon. The domestic monetary policy shocks are not the major sources of output fluctuations in New Zealand. Specifically, the domestic monetary policy shock $\left(\mathrm{R}_{\mathrm{NZ}}\right)$ explains 7.3 percent fluctuations in New Zealand output at the peak for a trade partnership with Japan. On the other hand, the foreign monetary policy shock explains approximately 10 percent variations in New Zealand output at the peak for a trade partnership with the UK. Kim and Roubini (2000) reports similar findings for the non-US G-7 countries. 


\section{Conclusions}

The empirical models of monetary transmission in this paper comprehensively include domestic and foreign variables suggested by the theoretical NOEM model. The identification scheme of this study seems quite successful in identifying the domestic and foreign monetary policy shocks as the New Zealand industrial production exhibits plausible dynamic shock response in line with the channels of international monetary transmission mechanism. In other words, no significant empirical puzzles are observed. However, the intensity and magnitude of the output effects of the domestic monetary policy in New Zealand are found higher when the trade partnership with Australia and USA is included in the analysis. On the other hand, the full effect of domestic monetary policy on domestic output takes longer to realize and becomes less intense when the trade partnership with Japan and UK is considered. Finally, the domestic monetary policy shocks explain a relatively small percentage of output fluctuations compared to foreign monetary policy shocks. Specifically, it is observed that 'world non-oil commodity price index' explains most of the variations in New Zealand industrial production and this finding supports the prior literature findings. 


\section{References}

Bernanke, Ben S. and Blinder, A. (October 1990). "The Federal Funds Rate and the Channels of Monetary Transmission”, NBER, Working Paper No. 3487.

Betts Caroline and Devereux Michael (2000). "Exchange rate dynamics in a model of pricing-to-market”, Journal of International Economics.

Cushman, D.O., and Zha, T. (1997). "Identifying monetary policy in a small open economy under flexible exchange rates”. Journal of Monetary Economics, 39: 433-448.

Dickey, D.A. and Fuller,W.A. (1979). "Distribution of the Estimators for Autoregressive Time Series with a Unit Root", Journal of the American Statistical Association, No. 74, pp. 427-31.

Enders, W. (1995). “Applied Econometric Time Series”, 1st Edition, John Wiley \& Sons, Inc.

Favero, Carlo A. (2001). “Applied Macroeconometrics”, Oxford University Press.

Johansen, S., and K. Juselius. 1990. "Maximum Likelihood Procedure for Inference on Cointegration-with Applications to the Demand for Money." Oxford Bulletin of Economics and Statistics 52, no. 2 (May): 169-210.

Johansen, S. (1992 c). "Determination of Cointegration Rank in the Presence of a Linear Trend”, Oxford Bulletin of Economics and Statistics, 54, 383-97.

Kim, S. and Roubini, N. (2000). "Exchange Rate Anomalies in the Industrial Countries: A Solution with a Structural VAR approach”, Journal of Monetary Economics, 45, 561586.

Lane, R. Philip, (2001). “The New Open Economy Macroeconomics: A Survey”, Journal of International Economics, 54 (2), pp. 235-266.

Lee, M., Nziramasanga, M., and Ahn, S.K. (2004). “Transformation Strategy and Economic Performance, Hungary and Poland”, Vol. 42, No. 1, Eastern European Economics.

Lütkepohl, H., and Reimers, H. E. (1992). "Impulse Response Analysis of Cointegrated Systems”, Journal of Economic Dynamics and Control, North- Holland, 16, 53-78.

Obstfeld, Maurice; Rogoff, Kenneth, (1995). "Exchange rate dynamics redux”, 103, 3; Journal of Political Economy.

Otani, Akira, (October 2002). "Pricing-to-Market (PTM) and the International Monetary Transmission: The New Open-Economy Macroeconomics Approach”, Monetary and Economic Studies.

Pantula, S.G. (1989). “Testing for Unit Roots in Time Series Data”, Econometric Theory, 5(2), 256-271.

Park, Y. J. and Phillips Peter, C.B. (1988,1989). "Statistical Inference in Regressions with Integrated Processes: Part 1”, Cowles Foundation Paper 715, Econometric Theory, No. 4, 468-497. 
Ramaswamy, R. and Sløk, T. (1998). "The Real Effects of Monetary Policy in the European Union: What Are the Differences?”, No. 2, Vol. 45, IMF Staff Papers.

Reserve Bank of New Zealand Bulletin Vol. 64 No. 1, Wellington, The Reserve Bank of New Zealand.

Sims, C. (1986). “Are Forecasting Models Usable for Policy Analysis?” Quarterly Review, pp. 2-16.

Sims, C. A., Stock, J.H. and Watson, M. W. (January 1990). “Inference in Linear Time Series Models with Some Unit Roots”, Vol.58, No.1, pp. 113-144, Econometrica.

Svensson, Lars. E. O. (November, 1997). "Inflation targeting in an open economy: Strict or flexible inflation targeting?”, A text of public lecture held at Victoria University of Wellington, New Zealand.

Verbeek, M. (2003). “A Guide to Modern Econometrics”, 2nd Edition, John Wiley \& Sons Ltd. 
Table 1

Unit Root Tests (Level)

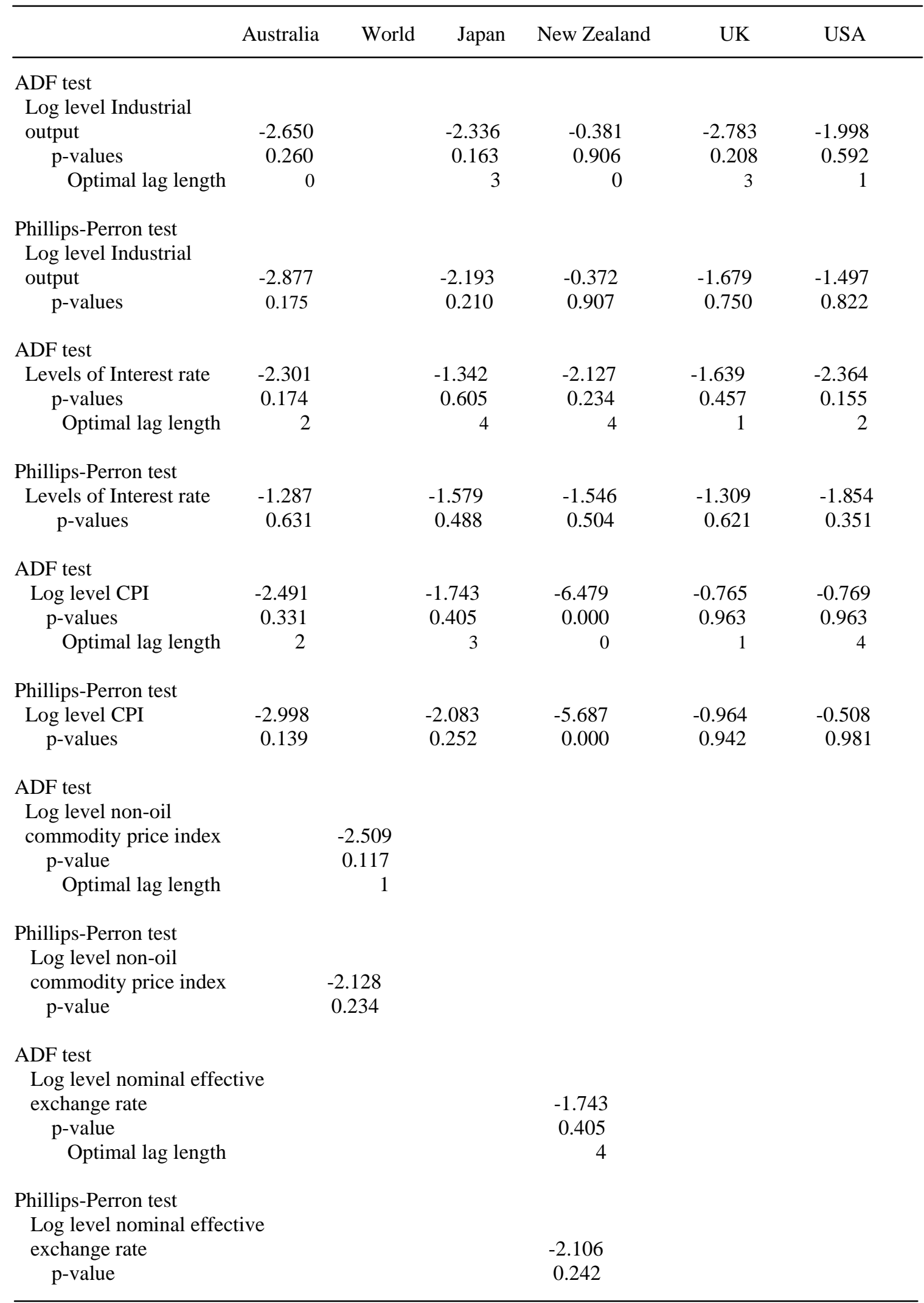

1. All data series are tested at 5\% significance level (both ADF and PP tests) complying McKinnon (1996) onesided critical values.

2. Hannan-Quinn criterion selects the optimal lag length for ADF test among maximum 4 lags.

3. Newey-West Bandwidth is selected for the Phillips-Perron test using Bertlett-kernel spectral method. 
Table 2

Unit Root Tests (Difference)

\begin{tabular}{|c|c|c|c|c|c|c|}
\hline & Australia & World & Japan & New Zealand & UK & USA \\
\hline \multicolumn{7}{|l|}{ ADF test } \\
\hline$\Delta(\log$ of industrial output) & -8.656 & & -4.483 & -8.640 & -3.977 & -3.979 \\
\hline p-values & 0.000 & & 0.000 & 0.000 & 0.002 & 0.002 \\
\hline Optimal lag length & 0 & & 2 & 0 & 1 & 0 \\
\hline \multicolumn{7}{|l|}{ Phillips-Perron test } \\
\hline$\Delta$ (log of industrial output) & -8.656 & & -4.404 & -8.641 & -7.976 & -3.979 \\
\hline p-values & 0.000 & & 0.000 & 0.000 & 0.000 & 0.002 \\
\hline \multicolumn{7}{|l|}{ ADF test } \\
\hline$\Delta$ (Interest rates) & -3.699 & & -3.418 & -7.204 & -5.565 & -5.341 \\
\hline p-values & 0.000 & & 0.000 & 0.000 & 0.000 & 0.000 \\
\hline Optimal lag length & 1 & & 3 & 3 & 0 & 0 \\
\hline \multicolumn{7}{|l|}{ Phillips-Perron test } \\
\hline$\Delta$ (Interest rates) & -6.236 & & -6.480 & -9.578 & -5.702 & -5.503 \\
\hline p-values & 0.000 & & 0.000 & 0.000 & 0.000 & 0.000 \\
\hline \multicolumn{7}{|l|}{ ADF test } \\
\hline$\Delta(\log$ of CPI $)$ & -2.633 & & -2.287 & -3.233 & -4.032 & -3.464 \\
\hline p-values & 0.091 & & 0.022 & 0.021 & 0.002 & 0.011 \\
\hline Optimal lag length & 2 & & 2 & 1 & 0 & 1 \\
\hline \multicolumn{7}{|l|}{ Phillips-Perron test } \\
\hline$\Delta(\log$ of CPI $)$ & -5.234 & & -6.297 & -4.869 & -4.162 & -5.133 \\
\hline p-values & 0.000 & & 0.000 & 0.000 & 0.001 & 0.000 \\
\hline \multicolumn{7}{|l|}{ ADF test } \\
\hline \multicolumn{7}{|l|}{$\Delta(\log$ of commodity } \\
\hline price index) & & -4.618 & & & & \\
\hline p-values & & 0.000 & & & & \\
\hline Optimal lag length & & 0 & & & & \\
\hline \multicolumn{7}{|l|}{ Phillips-Perron test } \\
\hline \multicolumn{7}{|l|}{$\Delta(\log$ of commodity } \\
\hline price index) & & -4.689 & & & & \\
\hline p-values & & 0.000 & & & & \\
\hline \multicolumn{7}{|l|}{ ADF test } \\
\hline \multicolumn{7}{|l|}{$\Delta$ (log of nominal effective } \\
\hline exchange rate) & & & & -5.260 & & \\
\hline p-values & & & & 0.000 & & \\
\hline Optimal lag length & & & & 0 & & \\
\hline \multicolumn{7}{|l|}{ Phillips-Perron test } \\
\hline \multirow{2}{*}{\multicolumn{7}{|c|}{$\begin{array}{l}\Delta \text { (log of nominal effective } \\
\text { exchange rate) }\end{array}$}} \\
\hline & & & & -7.152 & & \\
\hline p-values & & & & 0.000 & & \\
\hline
\end{tabular}

1. $\Delta$

indicates first difference.

2. All data series are tested at 5\% significance level (both ADF and PP tests) complying McKinnon (1996) onesided critical values.

3. Hannan-Quinn criterion selects the optimal lag length for ADF test among maximum 4 lags.

4. Newey-West Bandwidth is selected for the Phillips-Perron test using Bertlett-kernel spectral method. 
Table 3

Co-integration Test Results (Trading partners: New Zealand-Australia)

\begin{tabular}{|c|c|c|c|c|c|}
\hline$H_{0}:$ & $\mathrm{r}$ & $n-r$ & Model 2 & Model3 & Model 4 \\
\hline \multicolumn{6}{|c|}{$\lambda_{\max }$ test: } \\
\hline & 0 & 8 & $89.40 \rightarrow$ & $86.84 \rightarrow$ & 95.03 \\
\hline & 1 & 7 & $69.60 \rightarrow$ & $69.51 \rightarrow$ & 73.61 \\
\hline & 2 & 6 & $52.96 \rightarrow$ & $52.96 \rightarrow$ & 56.80 \\
\hline & 3 & 5 & 47.77 & $31.12^{*}$ & 33.06 \\
\hline & 4 & 4 & 28.59 & 26.87 & 28.65 \\
\hline & 5 & 3 & 26.66 & 21.50 & 26.84 \\
\hline & 6 & 2 & 21.20 & 14.58 & 19.06 \\
\hline & 7 & 1 & 12.17 & 0.74 & 14.57 \\
\hline \multicolumn{6}{|c|}{ Trace Test: } \\
\hline & 0 & 8 & $348.38 \rightarrow$ & $304.15 \rightarrow$ & 347.66 \\
\hline & 1 & 7 & $258.98 \rightarrow$ & $217.31 \rightarrow$ & $252.63 \rightarrow$ \\
\hline & 2 & 6 & $189.37 \rightarrow$ & $147.80 \rightarrow$ & $179.02 \rightarrow$ \\
\hline & 3 & 5 & $136.40 \rightarrow$ & $94.84 \rightarrow$ & $122.21 \rightarrow$ \\
\hline & 4 & 4 & $88.63 \rightarrow$ & $63.71 \rightarrow$ & $89.14 \rightarrow$ \\
\hline & 5 & 3 & $60.04 \rightarrow$ & $36.84 \rightarrow$ & 60.49 \\
\hline & 6 & 2 & 33.37 & $15.33^{*}$ & 33.64 \\
\hline & 7 & 1 & 12.17 & 0.74 & 14.57 \\
\hline
\end{tabular}

1. Johansen (1992c) joint hypothesis test of both rank order and deterministic component based on Pantula principle.

2. ' $r$ '= number of co-integrating vector.

3. ' $n$ ' = number of variables in the unrestricted reduced form VAR(3) model.

4. Both tests are performed using 5\% critical values reported in Osterwald-Lenum (1992).

5. Arrows indicate that the corresponding null hypothesis regarding the number of co-integrating vector is rejected based on $5 \%$ critical value of the test statistic.

6. Test statistic value in bold typing with an asterisk as the superscript indicates the non-rejection of null hypothesis regarding the number of co-integrating vector.

Table 4

Lag Specification and Residual Tests: Trading Partners: New Zealand - Australia

Optimal lag: $3 \quad$ Lag selection criteria: FPE, HQ \& LR $\quad$ Final model estimated: VAR(3)

Wald Lag exclusion test: Unrestricted model: lag 3; Restricted model: lag 2

Test Report: $\chi_{64}^{2}$ (joint) $=205.911$, p-value $=1.11 \mathrm{e}-16$; Decision: Null hypothesis of lag 2 is rejected.

Inverted root of the characteristic

AR polynomial: $\quad$ Largest root $=0.995$, Modulus $=0.995$, Decision: VAR(3) is stable.

White Heteroskedastacity test; No cross terms (only levels and squares): $\chi_{1728}^{2}=1744.049$, p-value $=0.3884$.

Decision: No significant heteroskedasticity is detected in the estimated VAR(3) residuals.

Multivariate Normality tests: Lütkepohl (Orthogonalization: Choleski):

Test Report: Skewness (joint): $\chi_{8}^{2}=10.368$, p-value $=0.24$, Decision: No significant Skewness.

Kurtosis (joint): $\chi_{8}^{2}=72.675$, p-value $=0.00$, Decision: Significant excess Kurtosis is detected.

Jarque Bera (joint): $\chi_{16}^{2}=83.044$, p-value $=0.00$, Decision: Multivariate normality is rejected.

Breusch-Godfrey LM test: Lag 1; LM stat: 69.32, p-value $=0.302$, lag 2; LM stat: 110.8, p-value $=0.00$

Lag 3; LM stat: 71.50, p-value $=0.24$, lag 4; LM stat: 79.76, p-value $=0.08$. 
Table 5

\section{Lag Specification and Residual Tests: Trading Partners: New Zealand - USA}

Optimal lag: $4 \quad$ Lag selection criteria: AIC, FPE \& LR $\quad$ Final model estimated: VAR(2)

Wald Lag exclusion test: Unrestricted model: lag 2; Restricted model: lag 1

Test Report: $\chi_{64}^{2}($ joint $)=275.10$, p-value $=0.00$; Decision: Null hypothesis of lag 1 is rejected.

Inverted root of the characteristic

AR polynomial: $\quad$ Largest root $=0.988$, Modulus $=0.988$, Decision: $\operatorname{VAR}(2)$ is stable.

White Heteroskedastacity test; No cross terms (only levels and squares): $\chi_{1152}^{2}=1232.23$, p-value $=0.0497$

Decision: No significant heteroskedasticity is detected in the estimated VAR(2) residuals.

Multivariate Normality tests: Lütkepohl (Orthogonalization: Choleski):

Test Report: Skewness (joint): $\chi_{8}^{2}=2.589$, p-value $=0.957$, Decision: No significant Skewness.

Kurtosis (joint): $\chi_{8}^{2}=22.901$, p-value $=0.0035$, Decision: Significant excess Kurtosis is detected.

Jarque Bera (joint): $\chi_{16}^{2}=25.491$, p-value $=0.0616$, Decision: Multivariate normality is not rejected.

Breusch-Godfrey LM test: Lag 1; LM stat: 108.83, p-value $=0.00$, lag 2; LM stat: 68.67, p-value $=0.32$

Lag 3; LM stat: 74.19, p-value $=0.18$, lag 4; LM stat: 75.93, p-value $=0.14$.

Table 6

Forecast Error Variance Decomposition of New Zealand Industrial Output

\begin{tabular}{lcc}
\hline Trading partners $\quad$ Shocks & $\begin{array}{c}\text { Forecast horizon } \\
\text { (quarters) }\end{array}$ & New Zealand industrial output \\
\hline
\end{tabular}

New Zealand - $\quad$ New Zealand

Australia bank discount rate

$\begin{array}{cc}4 & 4.73 \\ 10 & 3.93 \\ 20 & 3.25 \\ 40 & 2.66 \\ & \\ 4 & 15.33 \\ 10 & 13.09 \\ 20 & 18.71 \\ 40 & 22.42\end{array}$

Australian short term

interest rate

$\begin{array}{cc}4 & 0.48 \\ 10 & 4.29 \\ 20 & 5.20 \\ 40 & 5.38\end{array}$

New Zealand nominal

Effective exchange rate

$\begin{array}{ll}4 & 4.22 \\ 10 & 5.65 \\ 20 & 5.14 \\ 40 & 4.53\end{array}$

1. All variables are in log except New Zealand bank discount rate and Australian short term interest rate. 
Table 7

Forecast Error Variance Decomposition of New Zealand Industrial Output

\begin{tabular}{|c|c|c|c|}
\hline Trading partners & Shocks & $\begin{array}{l}\text { Forecast horizon } \\
\quad \text { (quarters) }\end{array}$ & New Zealand industrial output \\
\hline \multirow[t]{4}{*}{ New Zealand-Japan } & $\begin{array}{l}\text { New Zealand bank } \\
\text { discount rate }\end{array}$ & $\begin{array}{r}4 \\
10 \\
20 \\
40\end{array}$ & $\begin{array}{l}7.36 \\
4.37 \\
3.21 \\
2.96\end{array}$ \\
\hline & $\begin{array}{c}\text { World non-oil } \\
\text { commodity price index }\end{array}$ & $\begin{array}{c}4 \\
10 \\
20 \\
40\end{array}$ & $\begin{array}{r}9.73 \\
8.68 \\
21.37 \\
23.07\end{array}$ \\
\hline & Japanese bank discount & $\begin{array}{r}4 \\
10 \\
20 \\
40\end{array}$ & $\begin{array}{l}1.81 \\
7.94 \\
5.97 \\
5.52\end{array}$ \\
\hline & $\begin{array}{l}\text { New Zealand nominal } \\
\text { Effective exchange rate }\end{array}$ & $\begin{array}{c}4 \\
10 \\
20 \\
40\end{array}$ & $\begin{array}{l}1.23 \\
1.40 \\
2.44 \\
2.65\end{array}$ \\
\hline New Zealand-UK & $\begin{array}{c}\text { New Zealand bank } \\
\text { discount rate } \\
\text { World non-oil } \\
\text { commodity price index }\end{array}$ & $\begin{array}{c}4 \\
10 \\
20 \\
40 \\
4 \\
4 \\
10 \\
20 \\
40 \\
\\
4 \\
10 \\
20 \\
40\end{array}$ & $\begin{array}{l}1.01 \\
1.57 \\
1.24 \\
1.44 \\
\\
10.30 \\
12.21 \\
16.75 \\
14.63 \\
\\
3.58 \\
4.79 \\
7.30 \\
9.98 \\
\\
4.96 \\
7.80 \\
6.44 \\
5.68\end{array}$ \\
\hline
\end{tabular}

1. All variables are in log except Bank discount rates in Japan and New Zealand and UK Treasury bill rate. 
Table 8

Forecast Error Variance Decomposition of New Zealand Industrial Output

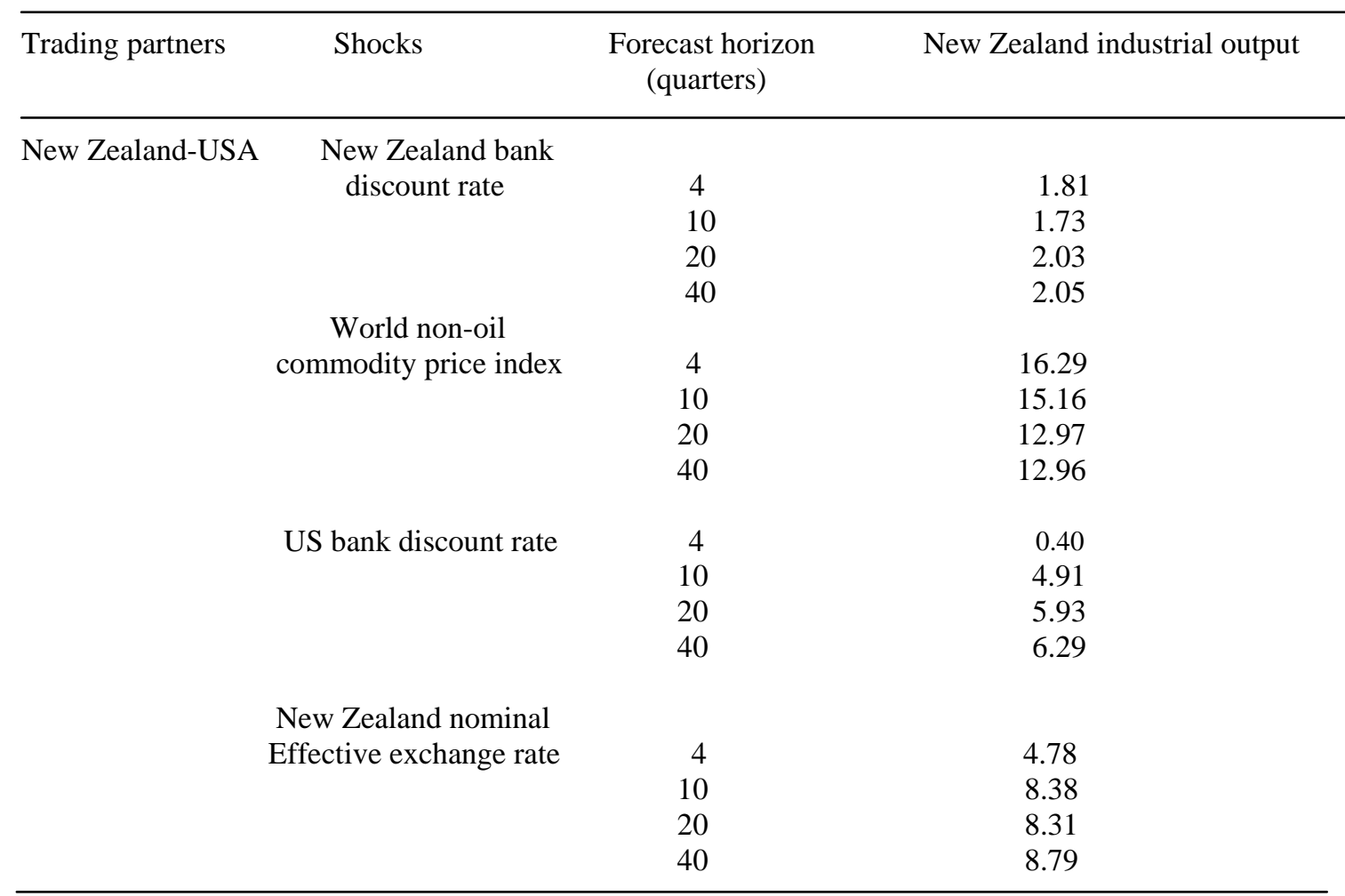

1. All variables are in log except Bank discount rates in New Zealand and in the USA. 
Figure 1

Real Effects of Domestic Monetary Policy Shocks in New Zealand

Trade partners: New Zealand-Australia

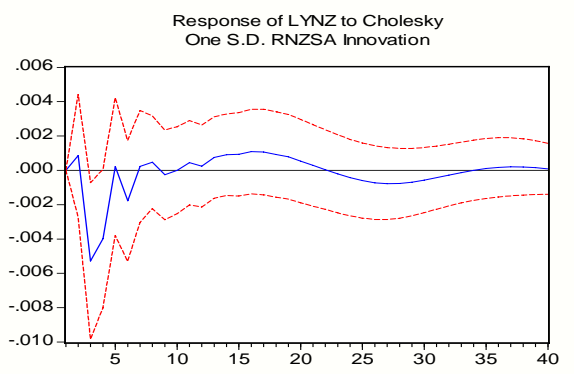

Trade partners: New Zealand-UK

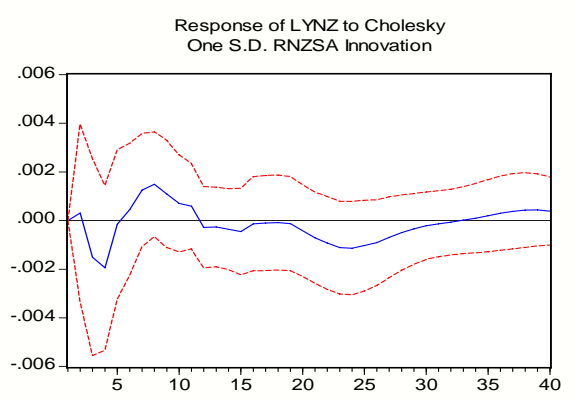

Trade partners: New Zealand-Japan

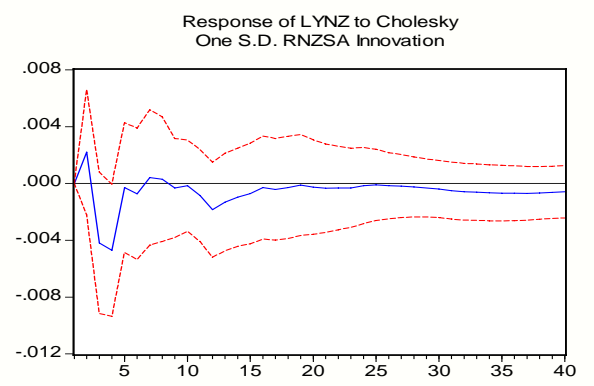

Trade partners: New Zealand-US

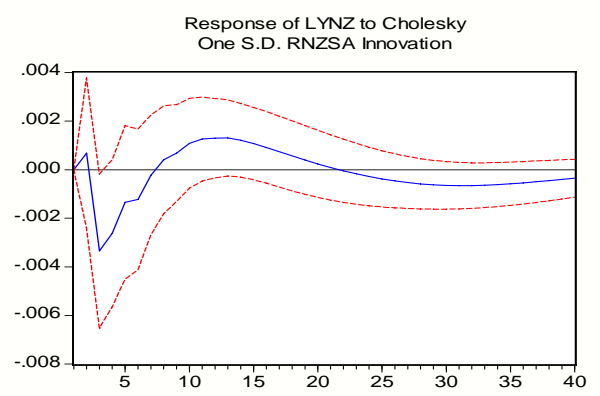


Figure 2

Real Effects of Foreign Monetary Policy Shocks in New Zealand

Trading partners: New Zealand-Australia ( $1^{\text {st }}$ row)
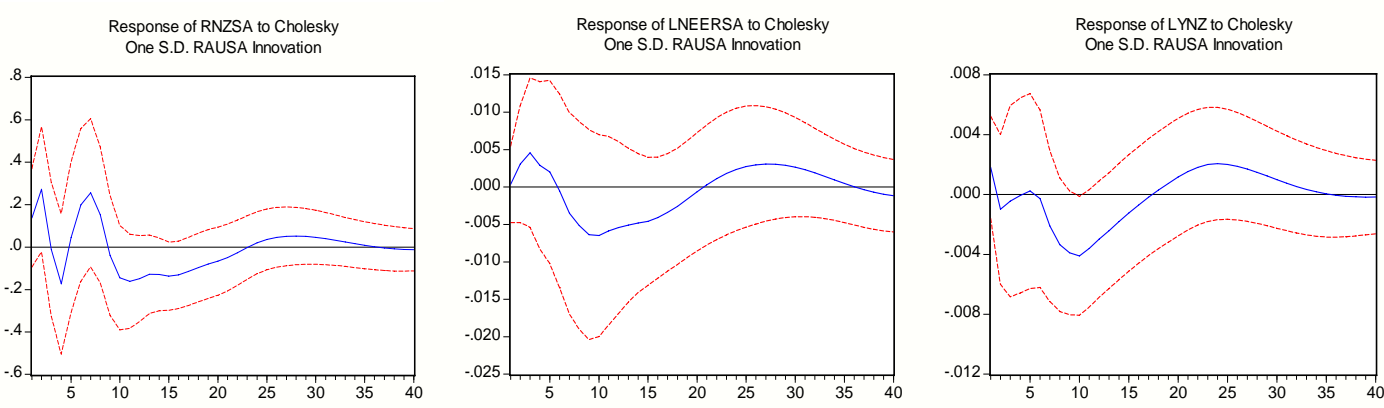

Trading partners: New Zealand-Japan ( $2^{\text {nd }}$ row)
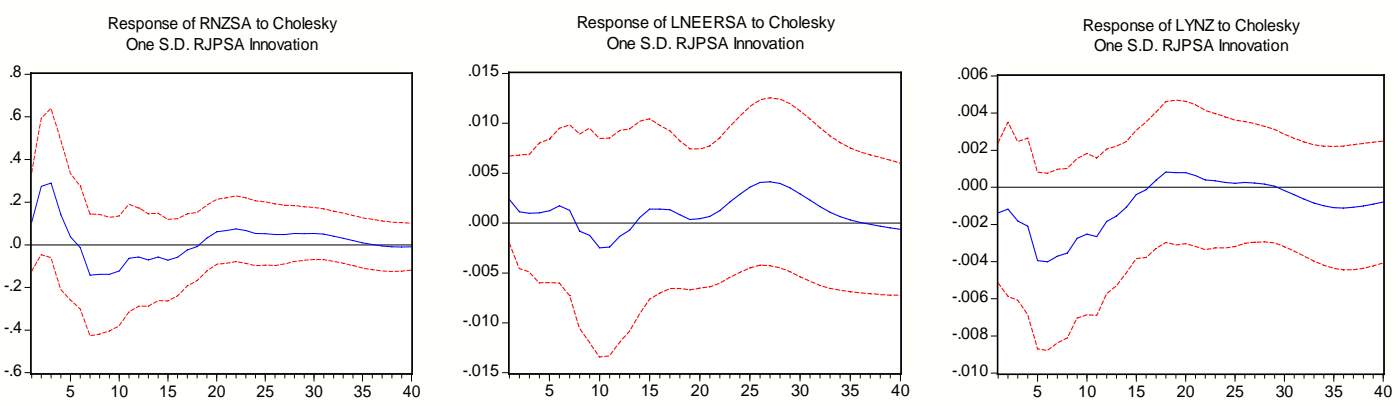

Trading partners: New Zealand-UK ( $3^{\text {rd }}$ row)
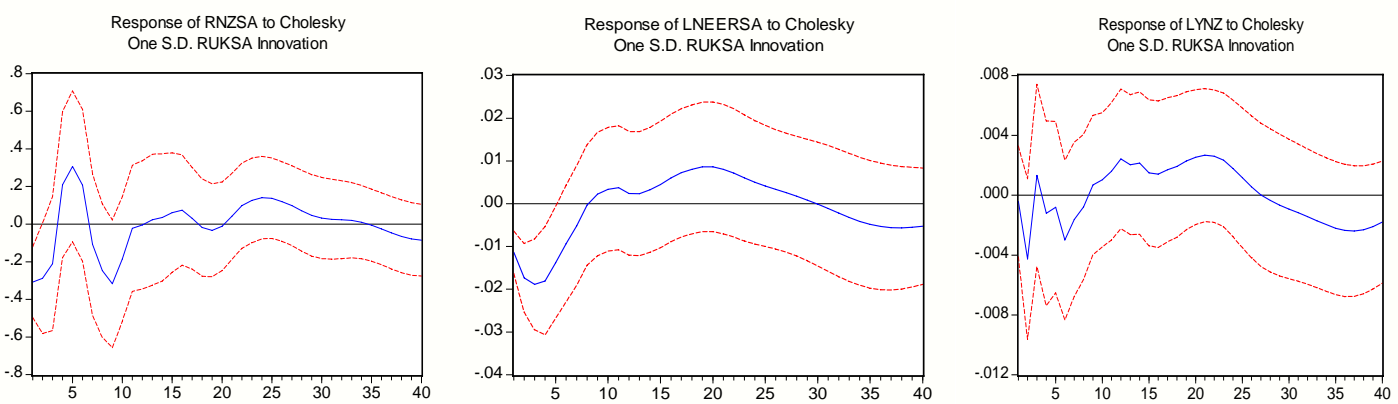

Trading partners: New Zealand-US (4 ${ }^{\text {th }}$ row)
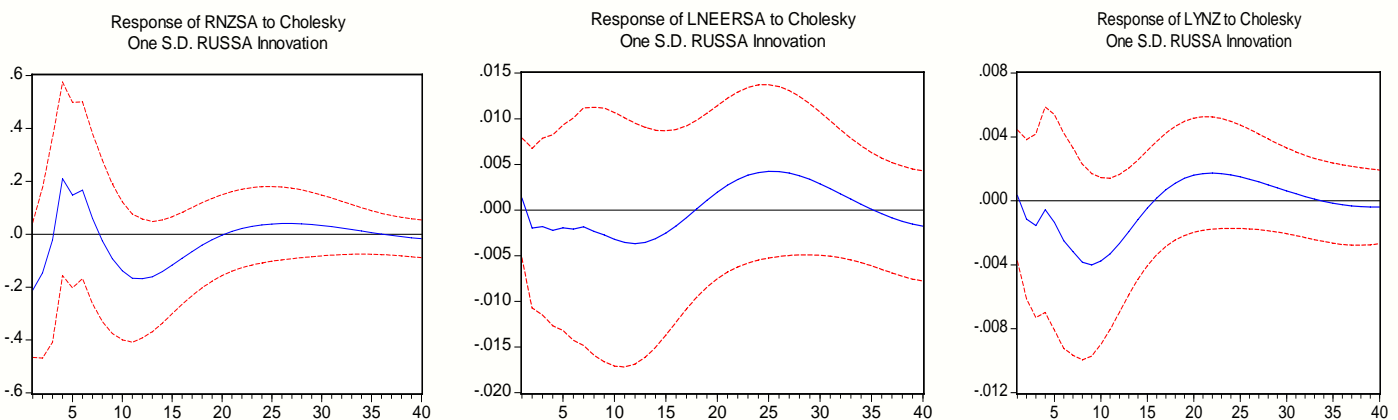